\title{
PERLINDUNGAN HUKUM PEMBELI APARTEMEN ATAU RUMAH SUSUN DI ATAS TANAH HAK PENGELOLAAN
}

\author{
Yusuf Saepul Zamil
}

Fakultas Hukum Universitas Padjadjaran

Jl. Dipati Ukur No. 35 Bandung

Email: yusuf.zamil@gmail.com

\begin{abstract}
The construction of apartments or flats whose land comes from management rights on behalf of the government is very potential to cause disputes between the government, pengembangs and owners of apartments. This can happen when the owner of the apartment will extend the Land Use Rights (HGB) over the land with the apartment's occupants being rejected by the government because the HGB on the land with the inhabitants of the apartment stands on the land with the right of management and coincidentally the government will use the land for the other interest. In this research, the analytic descriptive research specification is used, with normative legal approach method, that is approach method which focuses on library research which is secondary data supported by primary data. Ownership of apartments is evidenced by the certificate of Property Owned of Unit Flats should be equalized with the provisions of property rights such as ordinary residential homes, property rights there is no term as long as the apartment building is still standing. Therefore, the legal protection that should be given by the government to the owners of the HGB land alongside their apartment stood on the Right of Management, by giving recommendation of extension of HGB on Land Together by paying user charges in accordance with the prevailing provisions.
\end{abstract}

Keywords: Legal Protection, Apartment Residents, Government Land

\begin{abstract}
Abstrak
Pembangunan apartemen atau rumah susun yang tanahnya berasal dari hak pengelolaan atas nama pemerintah sangat potensial menimbulkan sengketa antara pemerintah, pengembang dan pemilik apartemen. Sengketa tersebut dapat terjadi ketika pemilik apartemen bersama para penghuni apartemen akan memperpanjang Hak Guna Bangunan (HGB) atas tanah. Permohonan tersebut akan ditolak oleh pemerintah karena HGB atas tanah tersebut berdiri di atas lahan yang berstatus hak pengelolaan dan pemerintah akan mempergunakan tanah tersebut untuk kepentingan umum. Dalam penelitian ini digunakan jenis penelitian deskriptif analitis, dengan metode pendekatan yuridis normatif, yaitu metode pendekatan yang menitikberatkan pada penelitian kepustakaan yang merupakan bahan hukum sekunder. Hasil penelitian menunjukkan kepemilikan atas apartemen dibuktikan dengan sertifikat Hak Milik Atas Satuan Rumah Susun yang harus dipersamakan dengan ketentuan hak milik seperti rumah hunian biasa, yaitu tidak ada jangka waktu sepanjang bangunan rumah susun masih berdiri. Bentuk perlindungan hukum yang harus diberikan pemerintah terhadap pemilik satuan rumah susun yang HGB nya berdiri di atas Hak Pengelolaan, yaitu dengan memberikan rekomendasi perpanjangan HGB Atas Tanah Bersama dengan membayar retribusi sesuai dengan ketentuan yang berlaku.
\end{abstract}

Kata Kunci: Perlindungan Hukum, Pembeli Apartemen, Hak Pengelolaan 


\section{Latar Belakang}

Tanah memegang peranan vital dalam kehidupan sebuah negara karena tanah merupakan sarana yang strategis untuk mencapai tujuan negara dalam mensejahterakan masyarakat. Di negara yang rakyatnya berhasrat melaksanakan demokrasi yang berkeadilan sosial, pemanfaatan tanah untuk sebesar-besar kemakmuran rakyat merupakan suatu syarat mutlak. ${ }^{1}$ Masyarakat Indonesia memandang tanah sebagai sarana tempat tinggal dan memberikan penghidupan sehingga tanah mempunyai fungsi yang sangat penting. Undang-undang Nomor 5 Tahun 1960 Tentang Peraturan Dasar Pokok-pokok Agraria (selanjutnya disebut UUPA) dalam pertimbangannya menegaskan bahwa hukum agraria nasional harus memberi kemungkinan akan tercapainya fungsi bumi, air, dan ruang angkasa, sesuai dengan kepentingan rakyat Indonesia dan perkembangan zaman serta merupakan perwujudan asas KeTuhanan Yang Maha Esa, Perikemanusiaan, Kebangsaan, Kerakyatan, dan Keadilan Sosial. ${ }^{2}$

Pemenuhan kebutuhan tempat tinggal masih menjadi salah satu masalah bagi Indonesia. Hal ini karena semakin mahalnya properti akibat lahan yang sempit di daerah perkotaan, yang masih menjadi tempat utama masyarakat dalam mencari nafkah. Di Indonesia kebutuhan penyediaan rumah bagi masyarakat berkisar antara 820.000 hingga 1 juta rumah per tahunnya. Kebutuhan ini bisa dipenuhi sekitar 40 persen oleh private sector, sedangkan yang berasal dari intervensi pemerintah hanya sekitar 20 persen. Sisanya sebanyak 40 persen tidak dapat terpenuhi sehingga menjadi backlog. selisih kebutuhan masyarakat tersebut akan terus menumpuk hingga ke tahun-tahun selanjutnya. Kalau setiap tahun dibutuhkan sekitar 1 juta rumah dan hanya 60 persen yang bisa dipenuhi baik dari private maupun intervensi pemerintah, maka akan selalu ada backlog. Saat ini estimasinya ada 10-12 juta backlog rumah. ${ }^{3}$

Backlog adalah kesenjangan antara jumlah rumah yang dibangun dan jumlah rumah yang dibutuhkan rakyat. Padahal rumah tinggal adalah salah satu kebutuhan dasar manusia. Perumahan merupakan pemenuhan hak atas papan yang dijamin Undang-Undang Dasar NRI Tahun 1945 Pasal 28 H Ayat (1) yang mengamanatkan bahwa setiap orang berhak hidup sejahtera lahir dan batin, bertempat tinggal, dan mendapatkan lingkungan hidup yang baik dan sehat serta berhak memperoleh pelayanan kesehatan. Berdasarkan data dari Kementerian Perumahan Rakyat, Indonesia kekurangan rumah 15 juta unit dengan laju kebutuhan 800.000 unit rumah per tahun, sedangkan pasokan rumah baru dari pengembang rata-rata 200.000 unit per tahun.

1 Iman Sudiyat, Hukum Adat, Sketsa Asas, Yogyakarta, Liberty, 1978, hlm. 1.

2 Boedi Harsono, Hukum Agraria Indonesia Himpunan Peraturan-peraturan Hukum Tanah, Jakarta, Djambatan, 2007, hlm. 3.

3 Muhammad Ikhsan B, "Sri Mulyani: Backlog Perumahan Makin Meningkat, Bagaimana Solusinya?", http://www.bareksa.com/id/text/2017/03/27/sri-mulyani-backlog-perumahan-makin-meningkat-bagaimanasolusinya/15192/analysis, diakses tanggal 6 September 2017 pukul 01.00 WIB. 
Harga tanah yang terus naik membuat impian masyarakat untuk memiliki rumah idaman, khususnya di kawasan perkotaan semakin sulit terwujud. ${ }^{4}$

Kebutuhan tanah khususnya untuk perumahan pada saat ini semakin meningkat seiring dengan semakin bertambahnya jumlah penduduk, namun demikian ketersediaan tanah semakin terbatas, oleh karena itu untuk mensiasatinya pemerintah menggulirkan kebijakan pemenuhan kebutuhan masyarakat akan perumahan tidak lagi bersifat horizontal yang memerlukan area tanah yang luas seperti perumahan biasa pada umumnya, akan tetapi lebih bersifat vertikal yang tidak terlalu membutuhkan lahan yang cukup luas dengan membangun ke atas melalui pembangunan rumah susun atau apartemen.

Tahun 2016 pertumbuhan apartemen di Jakarta mencatat angka 3.317 unit. Semakin menyempitnya lahan yang tersedia di kota besar, seperti Jakarta, membuat para pengembang properti memilih membangun hunian tipe vertikal sebagai solusi. Hunian apartemen semakin diminati karena sebagian besar apartemen terletak di pusat kota yang sangat strategis dekat dengan kawasan perkantoran. $^{5}$

Hingga akhir 2016 sebanyak 5.164 unit dari 10 proyek apartemen membanjiri Jakarta sehingga menambah pasokan tahunan menjadi
19.271 unit apartemen. Tren pertambahan itu diprediksi terus terjadi hingga kurun waktu dua tahun mendatang dari sekarang. Berdasarkan riset Colliers International Indonesia, hingga 2019 nanti diprediksi akan terdapat sebanyak 114 gedung apartemen yang dibangun di Jakarta. Sebanyak 28.014 unit dari 49 gedung apartemen baru, bakal menghiasi ibu kota hingga akhir 2017. Pada tahun 2018, 49 gedung apartemen kembali akan dibangun dengan menghadirkan 23.739 unit baru. Setahun setelahnya, akan ada 16 gedung apartemen baru yang terdiri dari 7.623 unit, jadi, jika ditotal, hingga 2019 nanti Jakarta bakal mendapat tambahan 59.376 unit apartemen baru. ${ }^{6}$ Selain di Jakarta Apartemen semakin banyak di kota-kota besar Indonesia seperti Bandung, Surabaya, Makassar, Medan, Semarang dan kota-kota besar lainnya. Semakin berkembangnya pembangunan apartemen di kota-kota besar sudah seharusnya juga diimbangi dengan pengetahuan masyarakat tentang aspek hukum suatu apartemen, agar masyarakat menjadi paham sehingga tidak dirugikan ketika membeli apartemen.

Berbagai regulasi di bidang rumah susun yang telah diundangkan oleh pemerintah seperti Undang-undang Nomor 20 Tahun 2011 Tentang Rumah Susun diharapkan bisa mendorong percepatan pembangunan

4 Nirwono Joga, Hunian Untuk Rakyat, http://id.beritasatu.com/home/hunian-untuk-rakyat/95729, diakses tanggal 6 September 2017 pukul 01.15 WIB.

5 Daftar Apartemen Di Jakarta Pusat, https://www.rukamen.com/apartemen-di-Jakarta-Pusat, diakses 8 September 2017 pukul 11.00 WIB.

6 Ridwan Aji Pitoko, Dua Tahun ke Depan, 114 Gedung Apartemen Anyar Sesaki Jakarta, http://properti.kompas. $\mathrm{com} / \mathrm{read} / 2017 / 01 / 10 / 163315621 /$ dua.tahun.ke.depan.114.gedung.apartemen.anyar.sesaki.jakarta, diakses 8 September 2017 pukul 11.10 WIB. 
rumah susun sederhana sewa (rusunawa) dan rumah susun sederhana milik (rusunami). Pemerintah telah memberi kemudahan yang seluas-luasnya bagi pengembang dalam membangun proyek-proyek rumah susun agar bisa membantu masyarakat untuk lebih mudah memperoleh unit rumah susun.

Kemudahan dan keleluasaan yang diberikan pemerintah kepada pengembang selain berkaitan dengan pajak juga pemerintah memberikan kemudahan dan keleluasaan dalam penggunaan tanah yang dikuasai oleh pemerintah untuk kepentingan pembangunan rumah susun. Dalam praktik tanah yang akan digunakan untuk pembangunan rumah susun bisa berasal dari tanah yang dibeli dari masyarakat atau yang dikenal dengan Hak Guna Bangunan murni bisa juga berasal dari tanah yang dikuasai oleh pemerintah atau Hak Guna Bangunan di atas tanah hak pengelolaan.

Rumah Susun dapat dibangun di atas tanah hak pengelolaan sebagaimana diatur dalam Pasal 17 Undang-undang Nomor 20 Tahun 2011 Tentang Rumah Susun, menyatakan rumah susun dapat dibangun di atas tanah: a. hak milik; b. hak guna bangunan atau hak pakai atas tanah negara; dan c. hak guna bangunan atau hak pakai di atas hak pengelolaan. Khusus mengenai pembangunan rumah susun oleh pengembang berasal dari tanah Hak Guna Bangunan diatas hak pengelolaan akan sangat potensial menimbulkan sengketa antara pemerintah sebagai pemilik tanah, pengembang dan masyarakat dalam hal ini pembeli pemilik hak milik atas satuan rumah susun. Hal ini bisa terjadi pada saat pembeli atau penghuni rumah susun akan memperpanjang Hak Guna Bangunan atas tanah bersama para penghuni rumah susun ditolak oleh pemerintah karena Hak Guna Bangunan atas tanah bersama para penghuni rumah susun berdiri di atas lahan yang berstatus hak pengelolaan atas nama pemerintah dan pemerintah akan mempergunakan tanah tersebut untuk kepentingan yang lain.

Mengenai perlindungan hukum terhadap masyarakat pemegang hak milik atas satuan rumah susun yang akan memperpanjang Hak Guna Bangunan atas tanah bersamanya ditolak oleh pemerintah dengan alasan Hak Guna Bangunan atas tanah bersama penghuni rumah susun berdiri diatas tanah dengan status hak pengelolaan milik pemerintah, sehingga bagaimana dengan status dari hak milik atas satuan rumah susun yang dimiliki para penghuni rumah susun apakah akan hilang begitu saja atau para penghuni dapat mempertahankan hak-haknya.

Dalam penelitian ini memberikan pengetahuan hukum kepada masyarakat ketika akan membeli apartemen agar tidak dirugikan dan dilindungi hak-haknya. Berdasarkan latar belakang tersebut di atas, dalam artikel ini akan membahas mengenai perlindungan hukum terhadap pemegang Hak Milik Atas Satuan Rumah Susun yang Hak Guna Bangunan tanah bersamanya berdiri di atas Hak Pengelolaan atas nama pemerintah (tanah negara) berdasarkan sistem hukum 
nasional di Indonesia dan upaya hukum yang dapat dilakukan pemegang Hak Milik Atas Satuan Rumah Susun yang ketika akan memperpanjang Hak Guna Bangunan tanah bersamanya ditolak oleh pemerintah sebagai pemegang Hak Pengelolaan. Dalam penelitian ini digunakan jenis penelitian deskriptif analitis, dengan metode pendekatan yuridis normatif, yaitu metode pendekatan yang menitikberatkan pada penelitian kepustakaan yang merupakan bahan hukum sekunder.

\section{Pembahasan}

\section{A. Perlindungan Hukum Terhadap Pemegang Hak Milik Atas Satuan Rumah Susun yang Hak Guna Bangunan atas Tanahnya Berdiri di Atas Hak Pengelolaan.}

Negara diberikan kewenangan untuk mengatur tanah dan unsur-unsur sumber daya alam lainnya yang merupakan kekayaan nasional. Dalam hal ini negara berwenang mengatur dan menyelenggarakan peruntukan, persediaan, perencanaan, penguasaan, dan penggunaan tanah, serta pemeliharaan tanah meliputi juga bumi, air, dan ruang angkasa dalam batas seluruh wilayah Republik Indonesia dengan tujuan agar dapat dipergunakan untuk sebesar-besar kemakmuran rakyat. $^{7}$
Wewenang dan pelaksanaan Hak Menguasai oleh Negara atas Tanah dapat dilimpahkan kepada Pemerintah Daerah dalam medebewind, pada hakikatnya akan terbatas pada apa yang disebutkan dalam Pasal 2 Ayat (2) huruf a UUPA, yaitu wewenang mengatur dan menyelenggarakan peruntukan, penggunaan, persediaan dan pemeliharaan tanah. ${ }^{8}$ Isi wewenang Negara yang bersumber pada hak menguasai Sumber daya Alam oleh Negara tersebut semata-mata bersifat publik yaitu, wewenang untuk mengatur (wewenang regulasi). ${ }^{9}$

Wewenang Negara yang bersumber pada hak menguasai Negara sebagaimana tercantum dalam Pasal 2 Ayat (2) UUPA, dibatasi oleh isi hak tersebut, artinya Negara memberikan kekuasaan kepada yang mempunyai hak untuk menggunakan haknya, sebagai batas kekuasaan Negara. Isi hak adalah kewenangan-kewenangan yang dipunyai oleh pemegang hak atas tanah, berdasarkan hukum yang berlaku. Misalnya pemegang hak milik berwenang untuk menggunakan tanahnya, menjual tanahnya, memberikan tanahnya kepada pihak ketiga, menjaminkan dengan hak tanggungan atau gadai. Wewenang yang sudah dipunyai oleh pemegang hak atas tanah, menjadi batas kewenangan/kekuasaan Negara yang bersumber pada hak menguasai tanah oleh Negara. ${ }^{10}$

7 Boedi Harsono, loc.cit.

8 Urip Santoso, Hukum Agraria dan Hak-hak Atas Tanah, Jakarta, Kencana Prenada Media Grroup, 2008, hlm. 77.

9 Diah Pawestri Maharani, Pembatasan Hak Menguasai Negara Oleh Masyarakat Adat Dalam Pengelolaan Sumber Daya Air, Arena Hukum, V. 9, n. 1, hlm. 44, apr.2016. ISSN 2527-4406. Available at http://arenahukum. ub.ac.id/index.php/arena/article/view/236. doi:http://dx.doi.org/10.21776/ub.arenahukum.2016.00901.3.

10 Muhammad Bakri, Hak Menguasai Tanah Oleh Negara (Paradigma Baru Untuk Reforma Agraria), Malang: UB Press, 2011, hlm. 42. 
Pelimpahan pelaksanaan sebagian melainkan merupakan gempilan Hak kewenangan negara terhadap Hak Menguasai Menguasai oleh negara atas Tanah, gempilan olehnegaraatastanahselainkepadaPemerintah adalah pelimpahan wewenang sebagian Daerah dan masyarakat-masyarakat hukum kewenangan Negara dan tidak dapat adat, dapat juga dilakukan kepada Badan- dipindahtangankan. Hak Pengelolaan didaftar Badan Otorita, perusahaan-perusahaan negara dan perusahaan-perusahaan daerah, dengan pemberian penguasaan tanah-tanah tertentu dengan apa yang dikenal dengan sebutan Hak Pengelolaan. ${ }^{11}$ Pasal 2 Ayat (4) UUPA menyatakan hak menguasai dari negara tersebut pelaksanaannya dapat dikuasakan kepada daerah-daerah swatantra dan masyarakat hukum adat, sekedar diperlukan dan tidak bertentangan dengan kepentingan nasional.

Hak Pengelolaan dalam sistematika hak-hak penguasaan atas tanah tidak dimasukkan dalam golongan hak-hak atas tanah. Pemegang Hak Pengelolaan memang mempunyai kewenangan untuk menggunakan tanah yang dibebankan hak bagi keperluan usahanya, tetapi itu bukan tujuan pemberian hak tersebut kepadanya. Tujuan utamanya adalah bahwa tanah yang bersangkutan disediakan bagi penggunaan oleh pihak-pihak lain yang memerlukan. Dalam penyediaan dan pemberian tanah itu pemegang haknya diberi kewenangan untuk melakukan kegiatan yang merupakan sebagian dari kewenangan negara. ${ }^{12}$

Sehubungan dengan itu Hak Pengelolaan pada hakikatnya bukan hak atas tanah, tidak dapat dipindahtangankan sehingga

11 Boedi Harsono, Hukum Agraria Indonesia Sejarah Pembentukan Undang-undang Pokok Agraria, Isi dan Pelaksanaannya, Jakarta, Djambatan, 2007, hlm. 275.

12 Arie Sukanti Hutagalung, Markus Gunawan, Kewenangan Pemerintah Di Bidang Pertanahan, Jakarta, Rajawali Pers, 2008, hlm. 3.

13 Boedi Harsono, op.cit., hlm. 277. 
tidak memenuhi syarat untuk dapat dijadikan jaminan utang. Oleh karena itu menurut Undang-Undang Nomor 4 Tahun 1996 Tentang Hak Tanggungan, Hak Pengelolaan tidak dapat dijadikan sebagai obyek Hak Tanggungan. Hak Menguasai oleh negara atas tanah tidak akan hapus karena sebagai pelimpahan Hak Bangsa sehingga selama Negara Republik Indonesia masih ada sebagai negara yang merdeka dan berdaulat maka Hak Menguasai oleh negara atas tanah akan tetap ada. Hak Pengelolaan bukanlah hak atas tanah sebagaimana dimaksud dengan hak atas tanah yang dikenal dalam Pasal 16 UUPA, melainkan kewenangan dari hak menguasai negara. ${ }^{14}$

Salah satu wewenang yang terdapat dalam Hak Pengelolaan adalah menyerahkan bagian-bagian tanah Hak Pengelolaan kepada pihak ketiga. Berdasarkan wewenang ini, pemegang hak pengelolaan dapat membuat Perjanjian Penggunaan Tanah atau perjanjian kerjasama dengan pihak ketiga dalam rangka menggunakan bagian-bagian tanah Hak Pengelolaan. Dari Perjanjian Penggunaan Tanah atau perjanjian kerjasama ini, pihak ketiga akan mendapatkan Hak Guna Bangunan atau Hak Pakai atas tanah Hak Pengelolaan. ${ }^{15}$

Pasal 35 UUPA menyebutkan bahwa Hak Guna Bangunan adalah hak untuk mendirikan dan mempunyai bangunan di atas tanah yang bukan miliknya sendiri dalam jangka waktu paling lama 30 tahun dan atas permintaan pemegang hak dapat diperpanjang dengan 20 tahun. Hak Guna Bangunan dapat diperoleh dari tanah negara ataupun tanah (hak) milik orang lain. Hak Guna Bangunan berdasarkan Pasal 37 UUPA menegaskan bahwa Hak Guna Bangunan terjadi pada tanah yang dikuasai langsung oleh negara atau hak milik orang lain, sedangkan Pasal 21 Peraturan Pemerintah No. 40 Tahun 1996 tentang Hak Guna Usaha, Hak Guna Bangunan Dan Hak Pakai Atas Tanah menegaskan bahwa tanah yang dapat diberikan dengan Hak Guna Bangunan adalah yang berasal tanah negara, tanah hak pengelolaan, atau tanah hak milik.

BerdasarkanPasal29PeraturanPemerintah No. 40 Tahun 1996 tentang tentang Hak Guna Usaha, Hak Guna Bangunan Dan Hak Pakai Atas Tanah menyatakan Hak Guna Bangunan diatas tanah hak pengelolaan berjangka waktu untuk pertama kali paling lama 30 tahun, dapat diperpanjang untuk jangka waktu paling lama 20 tahun, dan dapat diperbarui haknya untuk jangka waktu paling lama 30 tahun. Perpanjangan jangka waktu atau pembaruan Hak Guna Bangunan diatas hak pengelolaan atas permohonan pemegang Hak Guna Bangunan setelah mendapat persetujuan tertulis dari pemegang hak pengelolaan. Permohonan perpanjangan jangka waktu atau pembaruan Hak Guna Bangunan diajukan selambat-lambat 2 tahun sebelum berakhirnya jangka waktu Hak Guna Bangunan tersebut atau perpanjangannya. Perpanjangan atau

14 Ida Nurlinda, Telaah Atas Materi Muatan Rancangan Undang-Undang Pertanahan, Jurnal Bina Mulia Hukum Fakultas Hukum Universitas Padjadjaran, Volume 1 Nomor 1 September 2015, hlm. 5.

15 Urip Santoso, Perolehan Hak Atas Tanah, Jakarta, Kencana, 2015, hlm. 100. 
pembaharuan Hak Guna Bangunan diatas Hak Pengelolaan dicatat dalam buku tanah pada Kantor Pertanahan Kabupaten/Kota.

Berkaitan dengan hal tersebut diatas, yang penting untuk diketahui oleh pembeli pembeli apartemen adalah mengenai jangka waktu Hak Guna Bangunan diatas tanah hak pengelolaan akan berakhir dan cara perpanjangan dan pembaruan Hak Guna Bangunan diatas tanah hak pengelolaan. Hal-hal tersebut tentunya akan menjadi bahan pertimbangan pembeli ketika akan membeli apartemen dengan Sertifikat Hak Milik Atas Satuan Rumah Susun.

Berdasarkan Pasal 1 angka 11 UndangUndang Rumah Susun Nomor 20 Tahun 2011 Tentang Rumah Susun menyatakan bahwa Sertifikat hak milik sarusun yang selanjutnya disebut SHM sarusun adalah tanda bukti kepemilikan atas Sarusun di atas tanah hak milik, hak guna bangunan atau hak pakai di atas tanah negara, serta hak guna bangunan atau hak pakai di atas tanah hak pengelolaan. Pengembang melalui Badan Pertanahan Nasional dapat menerbitkan Hak Milik Atas Satuan Rumah Susun (HMASRS) kepada pembeli rumah susun berdasarkan UndangUndang Rumah Susun Nomor 20 Tahun 2011 Tentang Rumah Susun dengan catatan bentuk kerja sama yang dilakukan dengan perjanjian perolehan Hak Guna Bangunan dengan memberikan uang pemasukan sebagai kompensasi diberikannya Hak Guna Bangunan di atas Hak Pengelolaan.

Dengan sistem kerja sama perjanjian perolehan Hak Guna Bangunan ini, maka untuk menghindari sengketa dikemudian hari dengan pihak pembeli dan pihak instansi pemerintah sendiri, maka pengembang wajib memberitahukan kepada calon pembeli bahwa Hak Guna Bangunan tanah bersama yang akan diterima pembeli merupakan Hak Guna Bangunan di atas Hak Pengelolaan yang dituangkan baik dalam Perjanjian Pengikatan Jual Beli (PPJB) maupun dalam Akta Jual Beli (AJB), sehingga pada saat Hak Guna Bangunan tanah bersama akan habis masa berlakunya, maka perhimpunan penghuni rumah susun wajib meminta ijin kepada instansi pemerintah sebagai pemegang hak pengelolaan dengan membayar retribusi yang besarannya ditentukan oleh instansi pemerintah sesuai dengan ketentuan peraturan perundang-undangan yang berlaku.

Pengembang idealnya dapat menerbitkan Hak Milik Atas Satuan Rumah Susun (HMASRS), apabila sistem kerja sama yang dilakukan menggunakan sistem kerja sama Built Operate Transfer (BOT), karena kerja sama dengan sistem BOT ada jangka waktu perjanjian kerja sama dan pada saat berakhirnya kerja sama dengan sistem BOT semua tanah dan bangunan harus dikembalikan kepada instansi pemerintah sebagai pemegang Hak Pengelolaan, sehingga apabila pengembang menerbitkan HMASRS maka akan timbul permasalahan hukum dikemudian hari antara pembeli, instansi pemerintah dengan pengembang. Hal ini disebabkan karena pembeli akan menganggap bahwa dengan sistem kepemilikan HMASRS, maka satuan rumah susun tersebut sudah sepenuhnya 
dimiliki pembeli sehingga tidak perlu dikembalikan kepada instansi pemerintah sebagai pemegang Hak Pengelolaan.

Berdasarkan Undang-undang Rumah Susun Nomor 20 Tahun 2011 Tentang Rumah Susun sistem pemilikan HMASRS berbeda dengan hak milik pada rumah biasa (landed house), yang sistem kepemilikan HMASRS mempunyai sistem kepemilikan bersama dan terpisah, yaitu kepemilikan terpisah pada satuan rumah susun masing-masing pembeli, sedangkan kepemilikan bersama pada tanah bersama yang dibagi secara proporsional sesuai dengan luas bangunan yang dimiliki oleh masing-masing pemilik rumah susun (strata title).

Instansi pemerintah sebagai pemegang Hak Pengelolaan dapat saja tidak memperpanjang lagi Hak Guna Bangunan atas tanah bersama yang ditempati pembeli sesuai dengan jangka waktu perjanjian Build Of Transfer (selanjutnya disebut BOT) dengan pengembang, sehingga seharusnya secara otomatis bangunan dan tanah dikembalikan lagi kepada instansi pemerintah, namun demikian pada praktiknya akan sangat sulit mengambil lagi bangunan dan tanah dari para penghuni rumah susun karena para penghuni rumah susun mempunyai dasar HMASRS yang telah dibelinya dari pengembang, sehingga akan sangat rentan terjadi sengketa yang berkepanjangan dengan para penghuni rumah susun.

Oleh karena itu konstruksi hukum terbaik apabila bentuknya kerja sama dengan sistem BOT antara pengembang dengan instansi pemerintah sebagai pemegang Hak Pengelolaan, maka kepada pembeli rumah susun dapat diberikan hak sewa dengan jangka waktu yang lebih lama sampai berakhirnya perjanjian BOT dengan instansi pemerintah atau dengan sistem hak pakai dengan jangka waktu mengikuti berakhirnya Hak Guna Bangunan atas tanah bersama, sehingga dapat memberikan perlindungan hukum bagi pembeli penghuni rumah susun dan bagi instansi pemerintah sendiri dapat lebih mengamankan aset dari Hak Pengelolaannya.

Pembeli apartemen penting untuk mengetahui bahwa antara pemegang hak pengelolaan dengan pengembang harus ada perjanjian kerjasama baik dalam bentuk BOT maupun bentuk perjanjian lainnya. Apapun itu bentuk perjanjiannya antara instansi pemerintah pemegang hak pengelolaan dengan pengembang sekurang-kurangnya berisikan tentang:

1. identitas para pihak yang bersangkutan;

2. letak, batas-batas dan luas tanah yang dimaksud;

3. jenis penggunaan;

4. macam hak yang akan diberikan kepada pihak ketiga;

5. jangka waktu dan kemungkinan untuk memperpanjang hak tersebut;

6. jenis bangunan-bangunan yang akan didirikan dan ketentuan status bangunan serta berakhirnya hak-hak atas yang diberikan; dan

7. jumlahuangdansyarat-syaratpembayaran serta persetujuan lain yang dianggap perlu, seperti tentang kemungkinan hak 
guna bangunan atau hak pakai dialihkan

kepada pihak ketiga. ${ }^{16}$

Walaupun isi perjanjian hanya untuk diketahui para pihak dalam perjanjian saja, tetapi tidak salahnya menanyakan isi perjanjian antara instansi pemerintah pemegang hak pengelolaan dengan pengembang, sedangkan kalau informasi mengenai status tanah dan legalitas tanah dan bangunan apartemen merupakan hak dari pembeli pembeli apartemen untuk mengetahui informasinya.

Pada saat ini khususnya di kota-kota besar, pembangunan apartemen atau rumah susun semakin gencar dilakukan, hal ini sebagai akibat terbatasnya lahan diperkotaan, sedangkan disisi lain permintaan hunian semakin meningkat. Banyak penawaran yang dilakukan oleh pengembang yang menawarkan penjualan unit hunian dengan pola atau strategi penjualan pre project selling, yakni penjualan yang dilakukan sebelum proyek pembangunan property dimulai. Pengembang biasanya menawarkan unit-unit hunian rumah susun sementara bangunan fisik yang ditawarkan pengembang biasanya masih dalam bentuk gambaran maket gedung maupun brosur. Di saat calon pembeli tertarik dengan penawaran seperti ini dan meyetujui penawaran dari pihak pengembang, biasanya bersepakat melakukan proses transaksi awal dalam bentuk pembayaran booking fee dan atau uang muka, meski benda yang ditawarkan secara fisik masih dalam bentuk lahan tanah, dan belum terwujud bangunan unit rumah susun sebagaimana yang ditawarkan.

Strategi penjualan pre project selling ini memang telah menjadi model pemasaran properti di Indonesia. Namun dibalik strategi penjualan demikian, sering dilupakan adanya konsekuensi-konsekuensi yuridis di dalam pelaksanaan transaksinya. ${ }^{17}$ Setelah pembeli setuju dengan harga dan model apartemen yang ditawarkan, maka dalam praktik dilakukan dengan Perjanjian Pengikatan Jual Beli (selanjutnya disebut PPJB), PPJB sendiri adalah suatu bentuk perjanjian sebelum dilaksanakannya jual beli hak atas tanah. ${ }^{18}$

Sebelum membeli satuan rumah susun, sebaiknyapembelicalon penghunirumahsusun terlebih dahulu memeriksa aspek legalitas atas lokasi proyek rumah susun yang akan dibangunnya. Pembeli calon penghuni rumah susun dapat meminta kepada pengembang foto copy sertifikat induk tanahnya guna memberikan kepastian mengenai keabsahan kepemilikan tanah yang akan dikembangkan menjadi area rumah susun. Selain itu pembeli dapat juga menanyakan izin lokasi dan izin mendirikan bangunan dari hunian yang akan dibeli. Upaya seperti ini merupakan langkah

16 A.P. Parlindungan, Hak Pengelolaan Menurut Sistem UUPA (Undang-Undang Pokok Agraria) Edisi Revisi, Bandung: Mandar Naju, 2015, hlm. 35.

17 Erwin Kallo, Panduan Hukum untuk Pemilik/Penghuni Rumah Susun (Kondominium, Apartemen dan Rusunami), Jakarta, Minerva Athena Pressindo, 2009, hlm. 24.

18 Supriyadi, Kedudukan Perjanjian Pengikatan Jual Beli Hak Atas Tanah Dalam Perspektif Hukum Pertanahan, Arena Hukum, V. 10, n. 2, hlm. 205, aug.2017. ISSN 2527-4406. Available at http://arenahukum.ub.ac.id/ index.php/arena/article/view/318. doi:http://dx.doi.org/10.21776/ub.arenahukum.2017.01002.3. 
aman sebelum pembeli memutuskan membeli unit apartemen atau rumah susun.

Langkah awal adalah memeriksa Hak Guna Bangunan dari proyek rumah susun tersebut apakah sudah ada sertifikat Hak Guna Bangunan induknya yang akan menjadi tanah bersama para penghuni rumah susun. Pengembang berbadan hukum PT diperbolehkan mendapatkan Hak Guna Bangunan atas tanahnya walaupun rumah susun itu bisa pula dibangun di atas tanah dengan status Hak Milik, Hak Guna Bangunan, Hak Pakai Atas Tanah Negara dan Hak Pengelolaan.

Pembeli calon penghuni rumah susun dapat juga mendatangi kantor pertanahan dimana rumah susun tersebut akan dibangun. Pembeli calon penghuni rumah susun dapat menanyakan hal-hal yang ingin diketahui mengenai Hak Guna Bangunan induk, seperti darimana Hak Guna Bangunan induk diperoleh pengembang, dari pembebasan lahan artinya dibeli dari masyarakat atau yang disebut dengan Hak Guna Bangunan murni atau Hak Guna Bangunan diatas tanah Hak Pengelolaan atau tanah Negara dan Hak Guna Bangunan rumah susun itu sedang dalam penguasaan bank atau tidak. Dengan mengetahui latar belakang status awal kepemilikan tanah proyek pembangunan, pembeli penghuni rumah susun dapat menilai apakah layak atau tidak membeli unit apartemen atau rumah susun di lokasi tersebut dan sekaligus dapat menilai kredibilitas pengembangnya.
Walaupun mempunyai karakteristik yang berbeda, lamanya kepemilikan Hak Milik Atas Satuan Rumah Susun harus dipersamakan dengan ketentuan hak milik seperti rumah hunian biasa sebagaimana diatur dalam ketentuan UUPA, yaitu hak milik tidak ada jangka waktu dan berlangsung untuk selama-lamanya sepanjang tidak terjadi peralihan hak oleh pemiliknya. Oleh karena itu perlindungan hukum yang harus diberikan pemerintah terhadap pemegang Hak Milik Atas Satuan Rumah Susun yang Hak Guna Bangunan tanah bersamanya berdiri di atas Hak Pengelolaan atas nama pemerintah, yaitu dengan menyetujui perpanjangan Hak Guna Bangunan atas tanah bersama yang diatasnya berdiri bangunan rumah susun yang sudah dihuni oleh para penghuni rumah susun.

Dari segi pandangan para filsuf penganut hukum kodrat dalam arti hukum moral, substansi hukum kodrat adalah hukum keadilan yang mengatur hubungan antar manusia. Aristoteles meletakkan dasar pemikiran tentang hak asasi ketika menyatakan bahwa hukum kodrat adalah keadilan yang mengacu pada pelestarian dan hormat pada kehidupan manusia dan hak-hak yang melekat padanya. ${ }^{19}$ Pemberian rekomendasi perpanjangan Hak Milik Atas Satuan Rumah Susun adalah bentuk perlindungan hukum terhadap pemegang Hak Milik Atas Satuan Rumah Susun yang Hak Guna Bangunan tanah bersamanya berdiri di atas Hak Pengelolaan dan penghormatan terhadap hak milik pribadi seseorang.

19 Maria S.W. Sumardjono, Tanah Untuk Kesejahteraan Rakyat, Yogyakarta: Bagian Hukum Agraria Fakultas Hukum Universitas Gadjah Mada, 2010, hlm. 5. 
Hak milik seseorang harus dilindungi oleh hukum, bahkan hal ini diatur dalam konstitusi Negara Indonesia, yaitu dalam Pasal $28 \mathrm{H}$ dalam Undang-Undang Dasar NRI Tahun 1945 yang menyatakan "Setiap orang berhak mempunyai hak milik pribadi dan hak milik tersebut tidak boleh diambil alih secara sewenang-senang oleh siapapun". Pasal 28 H Undang-Undang Dasar NRI Tahun 1945 merupakan amanat adanya larangan bagi siapapun melakukan tindakan pencabutan/ pengurangan hak atas tanah, pengambilan tanah hak milik secara sewenang-wenang, yang berdampak kepada kehilangan tempat tinggal, pekerjaan, harkat dan martabat, penghidupan yang layak, atau kenikmatankenikmatan dari hak milik atas tanah yang telah dimilikinya. ${ }^{20}$

Dasar hukum hak setiap warga Negara untuk mendapatkan hak milik atas tanah, tercantum dalam Penjelasan Umum II angka 2 UUPA, yang menyatakan “.....dengan berpedoman pada tujuan untuk mencapai sebesar-besar kemakmuran rakyat dalam rangka mencapai masyarakat yang adil dan makmur, Negara dapat memberikan tanah yang demikian itu kepada seseorang atau badan-badan hukum, dengan sesuatu hak menurut peruntukan dan keperluannya, seperti pemberian hak milik".

Pemberian hak milik atas tanah merupakan perwujudan dari pelaksanaan
Undang-Undang Dasar NRI Tahun 1945 Pasal 33 Ayat (3), yaitu untuk mencapai sebesarbesar kemakmuran rakyat dalam rangka mewujudkan masyarakat yang adil dan makmur. Hal ini dipertegas dalam Pasal 2 Ayat (3) UUPA, bahwa wewenang yang bersumber pada hak menguasai dari Negara digunakan untuk mencapai sebesar-besar kemakmuran rakyat dalam arti kebangsaan, kesejahteraan dan kemerdekaan dalam masyarakat dan Negara Hukum Indonesia yang merdeka, berdaulat, adil dan makmur. Hal ini sejalan dengan tugas yang diemban oleh Negara Kesatuan Republik Indonesia sebagai Negara kesejahteraan (welfare state). Dalam arti bahwa tugas Negara untuk menyelenggarakan kesejahteraan rakyatnya, maka Negara sebagai organisasi kekuasaan seluruh rakyat diberi wewenang untuk memberikan hak milik atas tanah kepada warga Negara Indonesia. ${ }^{21}$

Hak Milik Atas Satuan Rumah Susun dapat diberikan diatas tanah Hak Guna Bangunan yang berasal dari Hak Pengelolaan pada perjanjian kerjasama pembangunan rumah susun antara pemerintah dengan pengembang, hanya saja pada saat HGB induknya berakhir, instansi pemerintah harus dapat memberikan rekomendasi perpanjangan HGB yang kemudian perpanjangan HGB dikeluarkan oleh Badan Pertanahan Nasional atas dasar rekomendasi dari instanasi pemerintah dan instansi pemerintah berhak mengelola

20 Adrian Sutedi, Implementasi Prinsip Kepentingan Umum Dalam Pengadaan Tanah Untuk Pembangunan, Jakarta: Sinar Grafika, 2007, hlm 54.

21 JW. Muliawan, Pemberian Hak Milik Untuk Rumah Tinggal, Sebuah Kajian Normatif Untuk Keadilan Bagi Masyarakat, Jakarta: Cerdas Pustaka Publisher, 2009, hlm. 97. 
apartemen atau rumah susun apabila perjanjian kerjasama dengan pengembang berakhir.

\section{H. Upaya Hukum Pemegang Hak Milik Atas Satuan Rumah Susun atasPenolakan pemerintahSebagai Pemegang Hak Pengelolaan Dalam Permohonan Perpanjangan Hak Guna Bangunan Atas Tanah.}

Menetap dan mengelola kehidupan di lingkungan hunian apartemen atau rumah susun di Indonesia ternyata bukan permasalahan yang mudah karena banyak rangkaian prosedur yang harus diketahui dan dijalani oleh para pemilik atau penghuni rumah susun. Hal ini mengandung arti banyak persoalan yang harus ditata bersama mengingat tinggal dirumah susun bebebeda dengan tinggal dirumah hunian biasa. Perbedaan tersebut tercermin dalam hak kepemilikan serta kewajiban-kewajiban yang menyertai penghuni rumah susun. Dalam hal ini sering kali penghuni rumah susun menjadi pihak yang dirugikan sehingga perlu dipertegas lagi yang menjadi kewajiban-kewajiban pengembang dan hak-hak penghuni rumah susun.

Banyak kasus yang menimbulkan friksi hukum antara pemerintah, pengembang dan penghuni rumah susun yang memberikan indikasi kuat dan gambaran realistis bahwa persoalan yang dihadapi hunian rumah susun masih butuh penyelesaian bersama. Hal ini disebabkan masih tumpang tindihnya berbagai aturan yang ada, namun juga akibat keterbatasan akses informasi yang diterima pembeli penghuni rumah susun baik sebelum membeli satuan rumah susun maupun setelah menjadi penghuni rumah susun sehingga masih menjadi kendala tersendiri sampai saat ini.

Pembeli penghuni rumah susun membutuhkan akses informasi yang benar mengenai prosedur jual beli, kepemilikan rumah susun dan menjadi permasalahan status tanah yang dijadikan alas hak untuk mendirikan rumah susun. Transparansi menjadi persoalan utama yang harus disikapi oleh pengembang rumah susun, pemerintah dan pihak-pihak terkait agar tidak merugikan pembeli penghuni rumah susun karena tanpa transparansi hanya akan menimbulkan kecurigaan satu sama lain lainnya sehingga akan menjadi permasalahan yang akan timbul dikemudian hari.

Dalam praktik yang selama ini terjadi dalam penjualan rumah susun atau apartemen, banyak pengembang yang tidak transparan dan tidak jujur mengatakan kepada calon pembeli rumah susun atau apartemen bahwa tanah yang akan digunakan untuk membangun rumah susun atau apartemen merupakan tanah milik pemerintah.

Banyak pengembang yang lebih bersikap dan berorientasi profit sehingga tidak mengindahkan etika jual beli, pada akhirnya merugikan pembeli penghuni rumah susun. Implikasi yuridisnya adalah rumah susun yang dibangun diatas tanah hak pengelolaan milik pemerintah akan terjadi permasalahan ketika pembeli akan memperpanjang Hak Guna Bangunan tanah bersama dan 
perpanjangan Hak Guna Bangunan atas tanah bersama tersebut tidak disetujui oleh instansi pemerintah karena tanahnya tersebut akan ambil lagi oleh instansi pemerintah. Upaya hukum yang dapat dilakukan pembeli penghuni rumah susun adalah dengan meminta ganti rugi kepada pengembang untuk membeli tanah pemerintah sehingga pembeli tidak perlu keluar dari rumah susun yang sudah lama ditempati pembeli penghuni rumah susun.

Tanah yang berada diatas Hak Pengelolaan bisa diberikan hak atas tanah, termasuk Hak Guna Bangunan, menurut Pasal 33 Peraturan Menteri Negara Agraria/ Kepala Badan Pertanahan Nasional Nomor 9 Tahun 1999 Tentang Tata Cara Pemberian Dan Pembatalan Hak Atas Tanah Negara Dan Hak Pengelolaan, penyerahan penggunaan tanah yang merupakan bagian dari tanah Hak Pengelolaan kepada pihak ketiga oleh pemegang Hak Pengelolaan wajib dilakukan dengan pembuatan perjanjian tertulis antara pihak pemegang Hak Pengelolaan dan pihak ketiga yang antara lain memuat tentang jangka waktu pemberian hak atas tanah tersebut serta kemungkinan untuk memperpanjangnya.

Hak Guna Bangunan di atas tanah Hak Pengelolaan dapat diperpanjang atau diperbaharui atas permohonan pemegang Hak Guna Bangunan setelah mendapat persetujuan dari pemegang Hak Pengelolaan sebagaimana diatur dalam Pasal 26 Ayat (3) Peraturan Pemerintah No. 40 Tahun 1996 tentang Hak Guna Usaha, Hak Guna Bangunan dan Hak
Pakai Atas Tanah. Jadi, untuk perpanjangan/ pembaruan Hak Guna Bangunan tersebut memang harus atas persetujuan pemegang Hak Pengelolaan. Akan tetapi, tidak ada jaminan permohonan perpanjangan Hak Guna Bangunan di atas Hak Pengelolaan tersebut pasti akan disetujui oleh pemegang Hak Pengelolaan.

Jika pemegang Hak Pengelolaan tidak memberikan persetujuan, maka jangka Hak Guna Bangunan tidak diperpanjang/ diperbarui. Ini artinya jangka waktu Hak Guna Bangunannya berakhir, dan Hak Guna Bangunannya akan hilang. Hal ini sesuai dengan Pasal 35 Ayat (1) huruf a Peraturan Pemerintah No. 40 Tahun 1996, yang menyatakan bahwa salah satu alasan hapusnya Hak Guna Bangunan adalah berakhirnya jangka waktu sebagaimana ditetapkan dalam keputusan pemberian atau perpanjangannya atau dalam perjanjian pemberiannya. Tanah yang bersangkutan kembali ke dalam penguasaan sepenuhnya dari pemegang Hak Pengelolaan yang bersangkutan sebagaimana diatur dalam Pasal 36 Ayat (2) Peraturan Pemerintah No. 40 Tahun 1996. Mengenai pemegang Hak Milik atas Satuan Rumah Susun (HMSRS) yang dibangun di tanah Hak Guna Bangunan di atas Hak Pengelolaan, belum ada peraturan yang mengatur secara jelas bagaimana status Hak Milik Atas Satuan Rumah Susun jika Hak Guna Bangunan tersebut habis masa berlakunya.

Apabila instansi pemerintah pemegang hak pengelolaan menolak perpanjangan 
Hak Guna Bangunan, maka tindakan hukum yang dapat dilakukan oleh penghuni rumah susun dengan melakukan gugatan ganti rugi untuk menanggung biaya rekomendasi perpanjangan Hak Guna Bangunan, apabila dapat dibuktikan bahwa pada saat penjualan unit apartemen, pengembang menyembunyikan fakta bahwa apartemen berdiri diatas tanah Hak pengelolaan Instansi pemerintah. Tindakan hukum lain yang dapat dilakukan oleh penghuni rumah susun adalah dengan mengadakan negosiasi dengan pihak pemerintah pemegang hak pengelolaan agar pemerintah dapat memberikan ijin perpanjangan Hak Guna Bangunan Atas Tanah Bersama dengan memberikan retribusi sesuai dengan ketentuan yang berlaku.

Apabila pembeli membeli apartemen yang berada diatas tanah hak pengelolaan, maka pada saat habisnya jangka waktu Hak Guna Bangunan tanah bersama, pembeli akan dikenakan biaya rekomendasi perpanjangan dari instansi pemerintah dan biaya perpanjangan Hak Guna Bangunan itu sendiri dari Badan Pertanahan Nasional sebagai Penerimaan Negara Bukan Pajak. Adapun perhitungan besaran biaya rekomendasi berbeda-beda tergantung kebijakan dari instansi pemerintah pemegang Hak Pengelolaan. Sebagai contoh di DKI Jakarta besarannya rekomendasi perpanjangan Hak Guna Bangunan adalah berdasarkan Keputusan
Gubernur DKI Jakarta Nomor 122 Tahun 2001, Keputusan Gubernur DKI Jakarta Nomor 182 Tahun 2015 tentang Tata Cara Pemberian Rekomendasi Atas Permohonan Sesuatu Hak Di Atas Bidang Tanah Hak Pengelolaan Tanah Eks Desa Dan Tanah Eks Kota Praja Millk/dikuasai Pemerintah Provinsi Daerah Khusus Ibukota Jakarta, harga perpanjangan unit di atas Hak Pengelolaan $=5 \%$ luas lahan x NJOP (Nilai Jual Objek Pajak), ${ }^{22}$ sedangkan besaran pembayaran perpanjangan Hak Guna Bangunan contohnya adalah jika unit luasnya 40 meter persegi dan berada di atas tanah apartemen seluas 5 hektar (50.000 meter persegi), maka Hak Guna Bangunan yang harus ditanggung hanya 0,08\% (40/50.000 meter persegi). Jika waktu perpanjangan seluruh biaya nya adalah Rp 1 miliar, maka pemilik apartemen hanya menanggung $\mathrm{Rp}$ 800.000 sebagaimana diatur dalam Peraturan Pemerintah Nomor 13 tahun 2010 tentang Jenis dan Tarif Penerimaan Negara Bukan Pajak yang Berlaku pada Badan Pertahanan Nasional. ${ }^{23}$

Pembeli apartemen diatas tanah hak pengelolaan harus memeriksa jangka waktu Hak Guna Bangunan tanah bersamanya kapan jangka waktu berakhir, sebaiknya tidak membeli apartemen yang sebentar lagi habis Hak Guna Bangunan tanah bersamanya karena pembeli pembeli apartemen akan dibebani lagi biaya rekomendasi perpanjangan

22 Kelebihan dan Kekurangan Apartemen Status HPL, https://elshinta.com/news/26527/2015/09/21/kelebihandan-kekurangan-apartemen-status-hpl, diunduh tanggal 25 Agustus 2017 pukul 15.30.

23 Ini Hitungan Perpanjangan Sertifikat HGB Apartemen, https://www.rukamen.com/blog/ini-hitunganperpanjangan-sertifikat-hgb-apartemen/, diunduh tanggal 25 Agustus 2017 pukul 15.45. 
Hak Guna Bangunan dan biaya Hak Guna Bangunan perpanjangan Hak Guna Bangunan sendiri. Pada fakta hukumnya tidak semua pengembang memberitahukan secara transparan bahwa apartemen yang di jualnya itu berdiri diatas tanah hak pengelolaan dan bukan dari Hak Guna Bangunan. Seharusnya pengembang yang menjual unit apartemen menjelaskan asal tanah untuk membangun apartemen dari Hak Guna Bangunan diatas hak pengelolaan atau Hak Guna Bangunan murni karena berbeda akibat hukumnya. Apalagi dalam penjualan apartemen pembeli hanya berhubungan dengan marketing atau agen penjualan yang tidak semuanya paham mengenai legalitas suatu apartemen secara komprehensif.

Instansi pemerintah harus mempunyai alasan yang kuat dan dapat dipertanggung jawabkan dalam menolak perpanjangan Hak Guna Bangunan diatas hak pengelolaan, ketika izin pembangunan apartemen diberikan oleh instansi pemerintah tentunya harus sesuai dengan rencana tata ruang kabupaten/ kota, yaitu kawasan untuk perumahan dan permukiman. Oleh karena itu sepanjang tidak terdapat perubahan tata ruang, maka tidak ada alasan bagi instansi pemerintah untuk menolak perpanjangan Hak Guna Bangunan diatas hak pengelolaan. Dalam memutuskan suatu tanah negara untuk digunakan dalam memenuhi kebutuhan masyarakat akan tempat tinggal, maka instansi pemerintah harus menunjuk suatu lokasi (tanah) yang memang diperuntukkan untuk kawasan perumahan dan pemukiman dan tanah tersebut tidak akan pernah digunakan untuk peruntukkan lain seperti gedung perkantoran atau peruntukkan lain.

Instansi pemerintah pemegang Hak Pengelolaan mempunyai kewenangan untuk:

1. merencanakan peruntukan dan penggunaan tanah yang bersangkutan;

2. menggunakan tanah tersebut untuk keperluan pelaksanaan usahanya; dan

3. menyerahkan bagian-bagian daripada tanah itu kepada pihak ketiga menurut persyaratan yang ditentukan oleh perusahaan pemegang hak tersebut, yang meliputi segi-segi peruntukan, penggunaan, jangka waktu dan keuangannya, dengan ketentuan bahwa pemberian hak atas tanah kepada pihak ketiga yang bersangkutan dilakukan oleh pejabat-pejabat yang wewenang sesuai dengan peraturan perundangan agraria yang berlaku. ${ }^{24}$

walaupun pemegang hak pengelolaan mempunyai kewenangan untuk mengatur peruntukkan penggunaan tanah negara, tetapi kewenangan tersebut tidak dengan melanggar hak-hak masyarakat yang seharusnya dilindungi dalam hal ini hak-hak dari penghuni apartemen dengan Hak Milik Atas Satuan Rumah Susunnya.

Pembangunan apartemen diatas tanah hak pengelolaan seharusnya diperuntukkan bagi masyarakat berpenghasilan rendah. Oleh 
karena itu tidak ada alasan bagi pemerintah untuk menolak perpanjangan Hak Guna Bangunan, karena kewajiban pemerintah untuk menyediakan tempat tinggal bagi masyarakat yang tidak mampu. Konstruksi hukum yang dibangun seharusnya apartemen yang berdiri diatas tanah hak pengelolaan adalah dengan hak sewa atau pakai bagi masyarakat berpenghasilan rendah tidak dengan hak milik atas satuan rumah susun, hal ini untuk mencegah sengketa dengan penghuni apartemen dikemudian hari, dengan demikian perlu adanya penyesuaian terhadap Undangundang Rumah Susun Nomor 20 Tahun 2011 Tentang Rumah Susun.

Namun demikian pengembang biasanya tidak akan membangunkan apartemen kalau untuk disewakan atau dijual dengan hak pakai karena tidak mempunyai nilai jual, lainnya halnya kalau hak milik atas satuan rumah susun. Oleh karena seharusnya pemerinahlebih memberdayakan Badan Usaha Milik Daerah (BUMD) atau Badan Usaha Milik Nasional (BUMN) untuk memenuhi kebutuhan rumah untuk masyarakat berpenghasilan rendah.

Dalam menjual unit apartemen tidak harus selalu dengan Sertifikat Hak Milik Atas Satuan Rumah Susun dapat juga dengan Sertifikat kepemilikan bangunan gedung (SKBG) sebagaimana yang diatur dalam Pasal 1 angka 12 Undang-undang Rumah Susun Nomor 20 Tahun 2011 Tentang Rumah Susun, yang menyatakan sertifikat kepemilikan bangunan gedung sarusun yang selanjutnya disebut SKBG sarusun adalah tanda bukti kepemilikan atas sarusun di atas barang milik negara/daerah berupa tanah atau tanah wakaf dengan cara sewa. Namun demikian Sertifikat kepemilikan bangunan gedung (SKBG) masih belum dipraktekan dalam penjualan unit apartemen karena pengembang masih enggan menjual unit apartemen dengan Sertifikat kepemilikan bangunan gedung (SKBG).

Perjanjian kerjasama antara instansi pemerintah sebagai pemegang hak pengelolaan dan pengembang harus berakhir sampai jangka waktu Hak Guna Bangunan tanah bersamanya berakhir. Berdasarkan perjanjian dengan sistem BOT, maka gedung apartemen beserta fasilitas yang sudah dibangun menjadi milik instansi pemerintah sedangkan masyarakat hanya memiliki unit satuan rumah susun. Seiring berakhir perjanjian kerjasama antara instansi pemerintah dengan pengembang, maka instansi pemerintah berhak atas pengelolaan apartemen yang selama ini dikelola oleh pengembang. Instansi pemerintah pemegang hak pengelolaan akan mendapat pemasukan dari jasa pengelolaan apartemen dalam bentuk service charge yang dibayarkan oleh penghuni apartemen setiap bulannya. Oleh karena itu apabila instansi pemerintah menolak perpanjangan Hak Guna Bangunan, maka instansi pemerintah pemegang hak pengelolaan akan kehilangan sumber pendapatannya.

Hak milik adalah hak yang terkuat dan terpenuh, hak milik atas satuan rumah susun yang walaupun mempunyai karakteriktik yang berbeda dengan hak milik pada 
rumah hunian biasa, tetap harus mendapat perlindungan hukum seperti halnya hak milik pada rumah hunian biasa. Sebagai hak milik yang terkuat dan terpenuh maka hak milik tidak ada jangka waktu dan dapat diwariskan. Yang membedakan hanyalah hak milik satuan rumah susun berakhir apabila bangunan apartemennya hancur, sedangkan apabila bangunannya masih berdiri, maka hak milik atas satuan rumah susun harus tetap dilindungi. Oleh karena itu apabila perpanjangan Hak Guna Bangunan atas tanah bersamanya ditolak pemerintah, maka para penghuni rumah susun berhak mengajukan gugatan kepada pengadilan. Walaupun Hak Guna Bangunan atas tanah bersamanya berakhir, akan tetapi hak milik atas satuan rumah susun masih tetap berlaku sepanjang tidak ada peralihan hak, pembatalan hak atau bangunan apartemennya yang musnah. Oleh karena itu penghuni rumah susun dapat mempertahankan hak-haknya.

Musyawarah adalah jalan yang harus pertama kali ditempuh oleh para penghuni rumah susun dengan instansi pemerintah pemegang hak pengelolaan baik itu pemerintah kabupaten/kota, kementerian, BUMN, BUMD. Penyelesaian secara musyawarah ini sebaiknyamemintaBadanPertanahanNasional (BPN) sebagai mediator untuk menyelesaikan sengketa kepemilkan apartemen secara damai saling menghormati pihak-pihak yang bersengketa. Dalam musyawarah ini harus mengundang pengembang sehingga lebih jelas akar permasalahannya untuk kemudian dicarikan titik temunya. Dalam hal tercapai penyelesaian secara musyawarah, harus disertai dengan bukti tertulis sejak permulaan, yaitu dari surat pemberitahuan para pihak, berita acara rapat, sampai Akta Perdamaian. ${ }^{25}$

Apabila penyelesaian sengketa kepemilikan apartemen secara musyawarah tidak tercapai, maka tindakan hukum para penghuni rumah susun yang perpanjangan Hak Guna Bangunan nya ditolak instansi pemerintah dapat mengajukan gugatan kepada pengadilan baik secara perdata maupun tata usaha negara. Gugatan Tata Usaha Negara ditujukan kepada instansi pemerintah pemegang Hak Pengelolaan atas keputusannya menolak perpanjangan Hak Guna Bangunan para penghuni rumah susun. Gugatan secara perdata kepada pengadilan negeri dapat menyertakan pengembang sebagai tergugat apabila merugikan pembeli apartemen.

\section{Simpulan}

Jangka waktu kepemilikan Hak Milik Atas Satuan Rumah Susun harus dipersamakan dengan ketentuan hak milik seperti rumah hunian biasa sebagaimana diatur dalam ketentuan UUPA, yaitu hak milik tidak ada jangka waktu dan berlangsung untuk selamalamanya sepanjang tidak terjadi peralihan hak oleh pemiliknya. Oleh karena itu perlindungan hukum yang harus diberikan pemerintah

25 Ali, Achmad Chomzah, Seri Hukum Pertanahan III Penyelesaian Sengketa Hak Atas Tanah, Jakarta: Pretasi Pustaka Publisher, 2002, hlm. 31. 
terhadap pemegang Hak Milik Atas Satuan Rumah Susun yang Hak Guna Bangunan tanah bersamanya berdiri di atas Hak Pengelolaan atas nama instansi pemerintah, yaitu dengan menyetujui perpanjangan Hak Guna Bangunan atas tanah bersama yang diatasnya berdiri bangunan rumah susun yang sudah dihuni oleh para penghuni rumah susun.

Upaya hukum yang dapat dilakukan oleh penghuni rumah susun dengan melakukan gugatan ganti rugi untuk menanggung biaya rekomendasi perpanjangan Hak Guna Bangunan, apabila dapat dibuktikan bahwa pada saat penjualan unit apartemen, pengembang menyembunyikan fakta bahwa apartemen berdiri diatas tanah Hak pengelolaan Instansi pemerintah. Upaya hukum lain yang dapat dilakukan oleh penghuni rumah susun adalah dengan mengadakan negosiasi dengan pihak pemerintah pemegang hak pengelolaan agar pemerintah dapat memberikan ijin perpanjangan Hak Guna Bangunan Atas
Tanah Bersama dengan memberikan retribusi sesuai dengan ketentuan yang berlaku.

Dalam Undang-undang Rumah Susun Nomor 20 Tahun 2011 Tentang Rumah Susun perlu diatur dan dipertegas bahwa rumah susun yang dibangun diatas hak pengelolaan tidak dapat diterbitkan hak milik atas satuan rumah susun, melainkan kepada penghuni rumah susun hanya dapat diterbitkan hak sewa atau hak pakai. Pemerintah memberikan sanksi kepada pengembang yang dengan itikad tidak baik menyembunyikan informasi mengenai status tanah kepada pembeli penghuni rumah susun termasuk informasi mengenai status tanah apartemen. Pemerintah, pengembang dan penghuni apartemen sebaiknya menyelesaikan permasalahan status tanah apartemen yang berdiri diatas tanah hak pengelolaan sebelum jangka waktu Hak Guna Bangunan atas tanah bersamanya tersebut berakhir untuk meminimalisir dampak hukum yang akan terjadi. 


\section{DAFTAR PUSTAKA}

Buku

Adrian Sutedi, Implementasi Prinsip Kepentingan Umum Dalam Pengadaan Tanah Untuk Pembangunan, Jakarta: Sinar Grafika, 2007.

Ali, Achmad Chomzah, Seri Hukum Pertanahan III Penyelesaian Sengketa Hak Atas Tanah, Jakarta: Pretasi Pustaka Publisher, 2002.

A.P. Parlindungan, Hak Pengelolaan Menurut Sistem UUPA (Undang-Undang Pokok Agraria) Edisi Revisi, Bandung: Mandar Naju, 2015.

Arie Sukanti Hutagalung, Markus Gunawan,

Kewenangan Pemerintah Di Bidang Pertanahan, Jakarta, Rajawali Pers, 2008.

Boedi Harsono, Hukum Agraria Indonesia Himpunan Peraturan-peraturan Hukum Tanah, Jakarta, Djambatan, 2007.

Boedi Harsono, Hukum Agraria Indonesia, Sejarah Pembentukan Undang-undang Pokok Agraria, Isi dan Pelaksanaannya, Jakarta, Djambatan, 1994.

Erwin Kallo, Panduan Hukum untuk Pemilik/

Penghuni Rumah Susun (Kondominium, Apartemen dan Rusunami), Jakarta, Minerva Athena Pressindo, 2009.

Iman Sudiyat, Hukum Adat, Sketsa Asas, Yogyakarta, Liberty, 1978.

JW. Muliawan, Pemberian Hak Milik Untuk Rumah Tinggal, Sebuah Kajian Normatif Untuk Keadilan Bagi
Masyarakat, Jakarta: Cerdas Pustaka Publisher, 2009.

Maria S.W. Sumardjono, Tanah Untuk Kesejahteraan Rakyat, Yogyakarta: Bagian Hukum Agraria Fakultas Hukum Universitas Gadjah Mada, 2010.

Muhammad Bakri, Hak Menguasai Tanah Oleh Negara (Paradigma Baru Untuk Reforma Agraria), Malang: UB Press, 2011.

Urip Santoso, Hukum Agraria dan Hak-hak Atas Tanah, Jakarta, Kencana Prenada Media Grroup, 2008.

Urip Santoso, Perolehan Hak Atas Tanah, Jakarta, Kencana, 2015.

\section{Jurnal}

Diah Pawestri Maharani, Pembatasan Hak Menguasai Negara Oleh Masyarakat Adat Dalam Pengelolaan Sumber Daya Air, Arena Hukum, V. 9, n. 1, hlm. 44, apr.2016. ISSN 2527-4406. Available at http://arenahukum.ub.ac. $\mathrm{id} /$ index.php/arena/article/view/236. doi:http://dx.doi.org/10.21776/ ub.arenahukum.2016.00901.3.

Ida Nurlinda, Telaah Atas Materi Muatan Rancangan Undang-Undang Pertanahan, Jurnal Bina Mulia Hukum Fakultas Hukum Universitas Padjadjaran, Volume 1 Nomor 1 September 2016. 
Supriyadi, Kedudukan Perjanjian Pengikatan Jual Beli Hak Atas Tanah Dalam Perspektif Hukum Pertanahan, Arena Hukum, V. 10, n. 2, hlm. 205, aug.2017. ISSN 2527-4406. Available at http://arenahukum.ub.ac. $\mathrm{id} /$ index.php/arena/article/view/318. doi:http://dx.doi.org/10.21776/ ub.arenahukum.2017.01002.3.

\section{Naskah Internet}

Muhammad Ikhsan B, "Sri Mulyani: Backlog Perumahan Makin Meningkat, Bagaimana Solusinya?", http://www. bareksa.com/id/text/2017/03/27/ sri-mulyani-backlog-perumahanmakin-meningkat-bagaimanasolusinya/15192/analysis, diakses tanggal 6 September 2017.

Nirwono Joga, Hunian Untuk Rakyat, http:// id.beritasatu.com/home/hunianuntuk-rakyat/95729, diakses tanggal 6 September 2017.

Ridwan Aji Pitoko, Dua Tahun ke Depan, 114 Gedung Apartemen Anyar Sesaki Jakarta, http://properti.kompas.com/ $\mathrm{read} / 2017 / 01 / 10 / 163315621 /$ dua . tahun.ke.depan.114.gedung.apartemen. anyar.sesaki.jakarta, diakses 8 September 2017.

Kelebihan dan Kekurangan Apartemen Status HPL, https://elshinta.com/ news/26527/2015/09/21/kelebihandan-kekurangan-apartemen-status-hpl, diakses 25 Agustus 2017.
Ini Hitungan Perpanjangan Sertifikat HGB Apartemen, https://www.rukamen. com/blog/ini-hitungan-perpanjangansertifikat-hgb-apartemen/, diakses 25 Agustus 2017.

Daftar Apartemen Di Jakarta Pusat, https:// www.rukamen.com/apartemen-diJakarta-Pusat, diakses 8 September 2017.

\section{Peraturan Perundang-undangan}

Undang-undang Nomor 5 Tahun 1960 Tentang Peraturan Dasar Pokok-pokok Agraria Undang-undang Rumah Susun Nomor 20 Tahun 2011 Tentang Rumah Susun Undang-Undang Nomor 4 Tahun 1996 Tentang Hak Tanggungan

Peraturan Pemerintah Nomor 40 Tahun 1996 tentang Hak Guna Usaha, Hak Guna Bangunan Dan Hak Pakai Atas Tanah

Peraturan Meteri Negara Agraria/ Kepala Badan Pertanahan Nasional Nomor 9 Tahun 1999 Tentang Tata Cara Pemberian Dan Pembatalan Hak Atas Tanah Negara Dan Hak Pengelolaan

Peraturan Pemerintah 13 Tahun 2010 tentang Jenis dan Tarif Penerimaan Negara Bukan Pajak yang Berlaku pada Badan Pertahanan Nasional

Keputusan Gubernur DKI Jakarta Nomor 182 Tahun 2015 tentang Tata Cara Pemberian Rekomendasi Atas Permohonan Sesuatu Hak Di Atas Bidang Tanah Hak Pengelolaan Tanah Eks Desa Dan Tanah Eks Kota Praja Millk/dikuasai Pemerintah Provinsi Daerah Khusus Ibukota Jakarta 